\title{
The connection between antisocial creativity and values of students of pedagogical specialties
}

\author{
Ilia $V$. Egorov $^{1 *}$, Diana $V$. Naumova $^{1}$, Tatiana A. Pavlenko ${ }^{1}$, Irina N. Rasskazova ${ }^{2}$, and \\ Stepan A. Kuts ${ }^{3}$ \\ ${ }^{1}$ Moscow City University, Institute of Pedagogy and Psychology of Education, Department of \\ Psychology, Moscow, Russia \\ ${ }^{2}$ Omsk State Pedagogical University, School of Primary, Preschool and Special Education, Pedagogy \\ and Psychology of Childhood, Omsk, Russia \\ ${ }^{3}$ University of Bayreuth, Faculty of Languages \& Literatures, Intercultural German Studies, Bayreuth, \\ Germany
}

\begin{abstract}
Scholars study various aspects of creativity: features of a creative personality; the impact of creativity on society; mechanisms and conditions for the development of creativity. Creativity is productive, makes the life of a person and society better, as well as promotes progress. At the same time, the phenomenon of creativity is not so definite since scholars distinguish such a variety as antisocial creativity, in which a person uses one's creative potential against society and other people. This is reflected in specific research concerned with this phenomenon. It emphasizes the negative influence of the antisocial creativity of teachers on the forming personality of students and the effectiveness of education. The study objective is to study the antisocial creativity of future teachers and its connection with values and basic beliefs. The methods of testing, polling, mathematical statistics (correlation analysis) were used in the course of the study. This empirical study has revealed strong links between antisocial creativity and the age of respondents. As a result, antisocial creativity is connected with such values of social groups as conformism, tradition (inverse correlation); selfdirection, power and achievement (direct correlation). A negative correlation with the humor scale allows the authors to conclude that this type of antisocial creativity is a kind of defense. For the first time, this ascertaining study has considered the specifics of antisocial creativity of students of pedagogical specialties with due regard to their beliefs and values. The promising areas of research on the antisocial creativity of future teachers include identifying both personal and social determinants of this phenomenon.
\end{abstract}

Keywords: personality; self-image; basic values; educational process.

\footnotetext{
* Corresponding author: egoroviv@mgpu.ru
} 


\section{Introduction}

Modern psychological and pedagogical studies address various aspects of creativity: features of a creative personality; its impact on general personality and society; formation factors; mechanisms and conditions for its development, etc. Many foreign [1,2] and Russian [3-5] scholars paid attention to this phenomenon. Since the second half of the $20^{\text {th }}$ century, a lot of scientific data have been accumulated in the process of considering this issue. This scientific interest is not accidental since creativity is productive, makes the life of a person and society better, as well as contributes to progress. However, the phenomenon of creativity is not so definite, and modern scholars distinguish such a variety as antisocial creativity, in which a person uses creative potential against society and other people. This idea was reflected in the definition of antisocial creativity given by N.V. Meshkova and S.N. Enikolopov: "solving an illegitimate task by illegitimate or destructive methods that harm other people" [6]. This type of creativity is destructive since it can cause harm. It can have such serious negative manifestations as corruption, terrorism, fraud, criminal behavior, etc. In view of this, the issue of antisocial creativity deserves careful consideration. Despite the relevance and importance of this topic, scholars have been studying it not for long [6,7]. For example, they considered such factors of antisocial creativity as personality anxiety [7], personal propensity for aggressive behavior [8], avoidance motive [9], emotional intelligence [10], unfair social circumstances [11]. The field of study embraced the following issues: the relationship between antisocial creativity and deceit $[12,13]$, the relationship between humor and creativity [14-16].

This issue is even more significant for education. This is due to the fact that the educational process involves the constant interaction between the teacher and students. In its course, the teacher has both direct and indirect influence on their personality [17]. This impact is done through the transmission of what the teacher says and does. Certain traits of the teacher's personality (values, attitudes, styles of interaction, mood, etc.) projected onto students are also of paramount importance. There is a possibility that teachers with pronounced antisocial creativity will influence the formation of these manifestations in young people. Therefore, the study of such manifestations will help to prevent them from influencing those students with whom teachers will interact.

We have suggested that a determining factor in the manifestation of antisocial creativity might be personal values that determine one's inner world and interaction with others, including prosocial/asocial behavior [18].

The article aims at analyzing the degree of asocial creativity of future teachers and its relationship with values and basic beliefs.

\section{Methods}

The study used the following methods: the questionnaire "Behavioral patterns of antisocial creativity" (The Malevolent Creativity Behavior Scale (M. Runco[19]) adapted by Meshkova, Yenikolopov, Mitina [20]); Sh. Schwartz's model of basic personal values [18]. To determine the above-mentioned relationship, we used Spearman's rank coefficient of correlation. The research involved 109 young women and two young men aged from 18 to 23 . All of them were students of pedagogical universities in Moscow and Omsk.

\section{Results}

The results are presented in Table 1. 
Table 1. The connection between antisocial creativity and values and basic beliefs.

\begin{tabular}{|c|c|c|c|c|c|}
\hline \multirow[t]{2}{*}{ Techniques } & \multirow[t]{2}{*}{ Variables } & \multicolumn{4}{|c|}{ Behavioral patterns of antisocial creativity } \\
\hline & & $\begin{array}{c}\text { Harm } \\
\text { scale }\end{array}$ & Lie scale & $\begin{array}{c}\text { Humor } \\
\text { scale }\end{array}$ & $\begin{array}{c}\text { Integral } \\
\text { indicator of } \\
\text { antisocial } \\
\text { creativity }\end{array}$ \\
\hline & Age & $\begin{array}{l}-0.061 \\
\end{array}$ & -0.178 & -0.179 & $\begin{array}{l}-0.199 * \\
\end{array}$ \\
\hline \multirow{10}{*}{$\begin{array}{l}\text { Sh. Schwartz's } \\
\text { model of basic } \\
\text { personal values } \\
\text { (part 1) }\end{array}$} & Conformity & $-0.199 *$ & -0.145 & -0.160 & $-0.210^{*}$ \\
\hline & Tradition & -0.168 & -0.129 & $-0.346^{* *}$ & $-0.289 * *$ \\
\hline & Benevolence & -0.171 & 0.029 & -0.058 & -0.053 \\
\hline & Universalism & -0.122 & -0.037 & -0.026 & -0.113 \\
\hline & Self-Direction & 0.062 & 0.093 & 0.011 & 0.028 \\
\hline & Stimulation & -0.097 & 0.038 & 0.013 & -0.054 \\
\hline & Hedonism & -0.036 & 0.012 & 0.031 & -0.019 \\
\hline & Achievement & 0.065 & 0.037 & 0.024 & 0.063 \\
\hline & Power & $0.195 *$ & 0.081 & 0.114 & 0.130 \\
\hline & Security & -0.099 & -0.159 & -0.165 & $-0.212^{*}$ \\
\hline \multirow{10}{*}{$\begin{array}{l}\text { Sh. Schwartz's } \\
\text { model of basic } \\
\text { personal values } \\
\text { (part 2) }\end{array}$} & Conformity 2 & -0.029 & -0.094 & $-0.242 *$ & -0.160 \\
\hline & Tradition 2 & -0.060 & -0.108 & $-0.276^{* *}$ & $-0.211 *$ \\
\hline & Benevolence 2 & -0.106 & 0.090 & 0.105 & 0.037 \\
\hline & Universalism 2 & -0.143 & -0.015 & 0.144 & -0.049 \\
\hline & Self-Direction 2 & -0.049 & -0.073 & 0.176 & -0.037 \\
\hline & Stimulation 2 & -0.147 & 0.045 & 0.048 & -0.028 \\
\hline & Hedonism 2 & 0.041 & 0.165 & $0.213^{*}$ & 0.163 \\
\hline & Achievement 2 & 0.154 & $0.202 *$ & $0.235^{*}$ & $0.235^{*}$ \\
\hline & Power 2 & $0.306^{* *}$ & $0.200^{*}$ & $0.333^{* *}$ & $0.329 * *$ \\
\hline & Security 2 & 0.008 & -0.170 & -0.132 & -0.180 \\
\hline
\end{tabular}

Note: * the significance of correlation is 0.05 ; ** the significance of correlation is 0.01 .

The integral indicator of asocial creativity is associated with the age of the respondents $(\mathrm{r}=-0.199)$. It decreases as people get older. With advancing age, the level of awareness and self-regulation of an individual seems to increase, as well as the understanding of the need to follow norms and rules adopted in society. This assumption is partly confirmed by the inverse correlation of asocial creativity with values that express group interests: conformity $(\mathrm{r}=$ $0.210)$ and tradition $(r=-0.289)$. Conformity means that a person agrees with the opinion of the majority of group members and follows common norms even if they do not coincide with their ideas. The reason is the need to be accepted by a group or a fear of possible sanctions. Adherence to traditions can be viewed as an indicator of prosocial behavior, therefore asocial creativity is less evident in those who comply with this strategy or appreciate public safety $(\mathrm{r}=-0.212)$.

The integral indicator of asocial creativity has a significant connection with the values that express personal interests: tradition $(\mathrm{r}=-0.211)$, achievement $(\mathrm{r}=0.235)$ and power $(\mathrm{r}=0.329)$. The more expressed power and achievement are, the more antisocial creativity is manifested in one's behavior. In this case, the interests of other people are neglected. To achieve one's personal goals, any means can be used, including those that harm other parties in the interaction. Indeed, if the teacher has such tendencies, they are also manifested in relation to students. Given the dependent position of the latter, this behavior has a negative effect on the development of a student's personality.

The respondents with high indicators of power use harm $(\mathrm{r}=0.306)$ and lie $(\mathrm{r}=0.200)$ to resolve problems with their interaction partners. Lie is also typical of those with high indicators of achievement $(\mathrm{r}=0.202)$. Interaction, including the possibility of "biting jests" to achieve one's goals, can be used by the respondents with the following values: hedonism 
$(\mathrm{r}=0.213)$, achievement $(\mathrm{r}=0.235)$ and power $(\mathrm{r}=0.333)$. It is not common for future teachers with high indicators of social values: tradition $(\mathrm{r}=-0.346)$ and conformity $(\mathrm{r}=-0.242)$.

The respondents who are confident in the benevolence and justice of the world are less likely to show a tendency to harm $(\mathrm{r}=-0.195)$ or use jests $(\mathrm{r}=-0.196)$ when resolving difficult situations in communication with others.

\section{Discussion}

1. In Schwartz's theory, achievement and power belong to the group of values that protect a person from personal worries associated with their benefits. Thus, the significance of correlation suggests that a person uses lies and biting jests (types of antisocial creativity) as a means of manipulation to achieve their personal interests, relieve anxiety or threats, and stay safe. In general, average values of lie for all the respondents $(\mathrm{N}=111)$ were higher $(=6.2)$, if compared to those of harm $(=3.87)$ and humor $(=2.9)$. It can be assumed that lies and pranks as a model of behavior and antisocial creativity are used in adolescence as an acceptable option to satisfy personal needs, assert oneself and remain in a comfort zone. On the contrary, the respondents' indicators of such values were quite low. Therefore, most respondents did not have any serious problems in terms of antisocial creativity.

2. There is a negative correlation between humor and tradition $(\mathrm{r}=-0.238)$. Tradition belongs to a socially-oriented group of values that focuses, among other things, on self-preservation and avoidance of anxiety.

3. Based on the results obtained, we can put forward a hypothesis about possible factors that determine the manifestation of antisocial creativity. The main factor is the psychological defense of one's "self-image". People make rather high demands on themselves that are difficult to meet. In a situation of inconsistency, a person experiences frustration. To protect one's "self-image", an individual resorts to lie as a mechanism of psychological defense aimed at eliminating negative emotions. They try to convince themselves that their behavior is appropriate, justify it or put thoughts and feelings associated with undesirable behavior into the unconscious. The behavior of people applying this model is based on their distrust of the world.

\section{Conclusion}

Further studies of the antisocial creativity of future teachers should determine significant personal and social determinants of this issue. It is also necessary to consider the influence this phenomenon has on both students and the educational process. Such a study will allow developing an adequate approach to its prevention and correction.

\section{References}

1. J.P. Guilford, Creativity: A quarter century of progress, in I.A. Taylor, and J.W. Getzels (Eds.), Perspectives in creativity, 37-59 (Aldine, Chicago, 1975)

2. R. Sternberg, T.I. Lubart, The concept of creativity: prospects and paradigms, in R. Sternberg (Ed.), Handbook of creativity, 3-31 (Cambridge University Press, Cambridge, 1999)

3. D.B. Bogoyavlenskaya, Psikhologiya tvorcheskikh sposobnostei [The psychology of creative skills] (Izdatelskii dom "Fedorov", Samara, 2009)

4. A.Ya. Ponomarev, Psikhologiya tvorchestva [The psychology of creativity] (Nauka, Moscow, 1976) 
5. A.I. Savenkov, Psikhologiya detskoi odarennosti [The psychology of gifted children] (Yurait, Moscow, 2020)

6. N.V. Meshkova, S.N. Enikolopov, Psikhologicheskaya Nauka i Obrazovanie, 22(5), 6776 (2017). https://doi.org/10.17759/pse.2017220508

7. M. Baas et al., Personality and Social Psychology Bulletin, 45(11), 1590-1602 (2019). https://doi.org/10.1177/014616721983855.

8. D.J. Harris, R. Reiter-Palmon, Psychology of Aesthetics, Creativity, and the Arts, 9, 5464 (2015). https://doi.org/10.1037/a0038499

9. E.Z. Woody, H. Szechtman, Neuroscience \& Biobehavioral Reviews, 35, 1019-1033 (2011). 10.1016/j.neubiorev.2010.08.003

10. D.J. Harris, R. Reiter-Palmon, J.C. Kaufman, Psychology of Aesthetics, Creativity, and the Arts, 7(3), 237-244 (2013). https://doi.org/10.1037/a0032139

11. Y. Cheng, M. Baas, C.K.W. De Dreu, Journal of Experimental Social Psychology, 74, 174-186 (2018)

12. J.J. Walczyk, M.A. Runco, S.M. Tripp, C.E. Smith, Creativity Research Journal, 20, 328-342 (2008)

13. M.L. Beaussart, C.J. Andrews, J.C. Kaufman, Thinking Skills and Creativity, 9, 129134 (2013)

14. I. Papousek, W. Ruch, C. Rominger, E. Kindermann, K. Scheidl, G. Schulter, et al., The use of bright and dark types of humor is rooted in the brain, Sci. Rep., 7, 42967 (2017). https://doi.org/10.1038/srep42967/

15. H.K. Lackner, K. Feyaerts, C. Rominger, B. Oben, A. Schwerdtfeger, I. Papousek, Psychophysiology, 56, e13320 (2019). https://doi.org/10.1111/psyp.13320/

16. C.M. Perchtold-Stefan, et al., Frontiers in Psychology, 11, 1213 (2020)

17. I.G. Dubov, V.A. Petrovskii, Perestrojka lichnostnyh struktur uchashchihsya pri personalizacii lichnosti pedagoga [Restructuring of students 'personal structures while personalizing the teacher's personality], in A.V. Petrovskii (ed.), Psikhologiya razvivayushcheisya lichnosti, 173-191 (Prosveshchenie, Moscow, 1987)

18. Sh. Schwartz, T.P. Butenko, D.S. Sedova, A.S. Lipatova, Psychology. Journal of the Higher School of Economics, 9(1), 43-70 (2012)

19. N. Hao, M. Tang, J. Yang, Q. Wang, M.A. Runco, Frontiers in Psychology, 7, 682 (2016). https://doi.org/10.3389/fpsyg.2016.00682.

20. N.V. Meshkova, S.N. Enikolopov, O.V. Mitina, I.A. Meshkov, Psikhologicheskaya Nauka i Obrazovanie, 23(6), 25-40 (2018). https://doi.org/10.17759/pse.2018230603 